\title{
Based on big data technology to effectively create university cultural and creative innovation and entrepreneurship platform*
}

\author{
SHEN JIAN ${ }^{1}$ \\ ${ }^{1}$ JILIN ANIMATION INSTITUTE Changchun, China
}

\begin{abstract}
There are some problems in the work of innovation and entrepreneurship in Colleges and universities, such as the difficulty of cultural and creative project management, the complexity of competition project selection process, the lack of curriculum system construction ideas, and the lack of innovation and entrepreneurship ability. Through the cloud platform, we can integrate the relevant data of innovation and entrepreneurship, and pass the multi-dimensional massive data through the unified portal Data cloud platform for interaction, customized interactive innovation and entrepreneurship services for each cultural and creative project entrepreneur, realized the clustering and sharing of entrepreneurial resources, unlimited expansion of entrepreneurial space, and benefit sharing in the era of big data.
\end{abstract}

\section{Introduction}

The university cultural and creative innovation and entrepreneurship cloud platform is based on the development of cultural and creative innovation and entrepreneurship. Through the data integration of cultural and creative entrepreneurship project management, expert tutor library construction, competition registration and online review, entrepreneurship and entrepreneurship activities, team building, cloud resource application, course resources and data analysis, the multi-dimensional massive user behavior data is analyzed through the unified platform One portal big data cloud platform for cross and interaction, give full play to the advantages of big data platform, focus on customizing interactive innovation and entrepreneurship services for each university entrepreneur, and ultimately achieve the purpose of comprehensively improving the innovation and entrepreneurship ability of university students, and provide new ideas and new experience for the development of University cultural and creative innovation and entrepreneurship work.

"Opinions of the general office of the State Council on the implementation of deepening the reform of innovation and entrepreneurship education in Colleges and universities" clearly points out that deepening the reform of innovation and entrepreneurship education in Colleges and universities is an urgent need for the country to implement the innovation driven development strategy and promote the quality, efficiency and upgrading of the economy. It is also an important measure to promote the comprehensive reform of higher education and promote higher quality entrepreneurship and employment of college graduates. "Opinions of the Ministry of education on vigorously promoting innovation and entrepreneurship education in Colleges and universities and college students' independent entrepreneurship work", "guiding opinions of the State Council on accelerating the construction of mass entrepreneurship and innovation support platform", "Notice of the general office of the Ministry of education on the construction of national talent pool of 10000 excellent innovation and entrepreneurship tutors" and "guidelines of the State Administration of foreign experts on Discipline Innovation of new colleges and universities in 2021" A series of documents, such as the notice on the establishment of smart base and the notice of the Ministry of education on doing a good job in the employment and Entrepreneurship of the 2021 graduates of ordinary colleges and universities in China, put forward more guiding opinions on the innovation and Entrepreneurship of colleges and universities

\section{The main problems of innovation and entrepreneurship in Colleges and Universitie}

\subsection{Cultural and creative project management is difficult}

Every year, major colleges and universities will apply for cultural and creative projects, which are generally organized by the academic affairs office or the student department, and initiated by individual students. After being approved by the departments and functional departments, they will report to the Ministry of education. Successful projects will be subject to an interim inspection in the implementation process, and will be concluded in the form of a final report at the end of the project. At present, all kinds of application and review process in Colleges and universities are to submit various paper 
materials, which is inefficient and not conducive to retention. In addition, cultural and creative projects can not effectively monitor the progress and cost of the project, and the project quality is difficult to guarantee.

\subsection{The selection process of cultural and creative innovation and entrepreneurship competition is complex}

Internet plus competition is Internet leading and youth competition. There are two major competitions in the country every year, namely, the Internet plus competition and the youth competition. The Internet plus competition is led by the Ministry of education. The competition is screened from the school matches to the Provincial Games and the national competitions. The annual "interconnection and competition" is from the national finals to the national finals, with a long time span and a long participation period. The "youth creation competition" is jointly sponsored by the Central Committee of the Communist Youth League, the Ministry of education and other units. All provinces and cities organize preliminaries or reviews for the participating projects, and the high-quality projects will participate in the national competition. When the participating colleges and universities select suitable projects to enter the competition, they basically adopt the way of manual audit, and the projects are reported to the administrative departments of the provincial and municipal education departments. When they participate in the provincial and national competitions, they still use Excel software for data collection and submission, which is inefficient and error prone, and the data is difficult to be used in association, so it is impossible to carry out complex data analysis and summary.

\subsection{Innovation and entrepreneurship curriculum system is lack of construction ideas}

The construction of innovation and entrepreneurship curriculum system is very important in the construction of innovation and entrepreneurship in Colleges and universities. At present, the number of universities with initial innovation and entrepreneurship curriculum system is less than $10 \%$ of the country's more than 3000 universities. If we can share the relevant data of innovation and entrepreneurship curriculum resources and curriculum system construction through the construction of big data and cloud platform, it will promote the reform and development of innovation and entrepreneurship education Speed.

\section{Construction and design of university cultural and creative innovation and entrepreneurship platform}

The innovation and entrepreneurship cloud platform in Colleges and universities mainly focuses on innovation and entrepreneurship, and provides strong technical support in entrepreneurial project management, expert tutor library construction, competition registration and online review, entrepreneurship and entrepreneurship activities, team building and cloud resource application. In addition, it also provides curriculum system construction resources, as well as docking with the corresponding business platform of higher authorities. The management process of university cultural and creative innovation and entrepreneurship cloud platform can be customized according to the needs.

\subsection{Module 1 - project declaration}

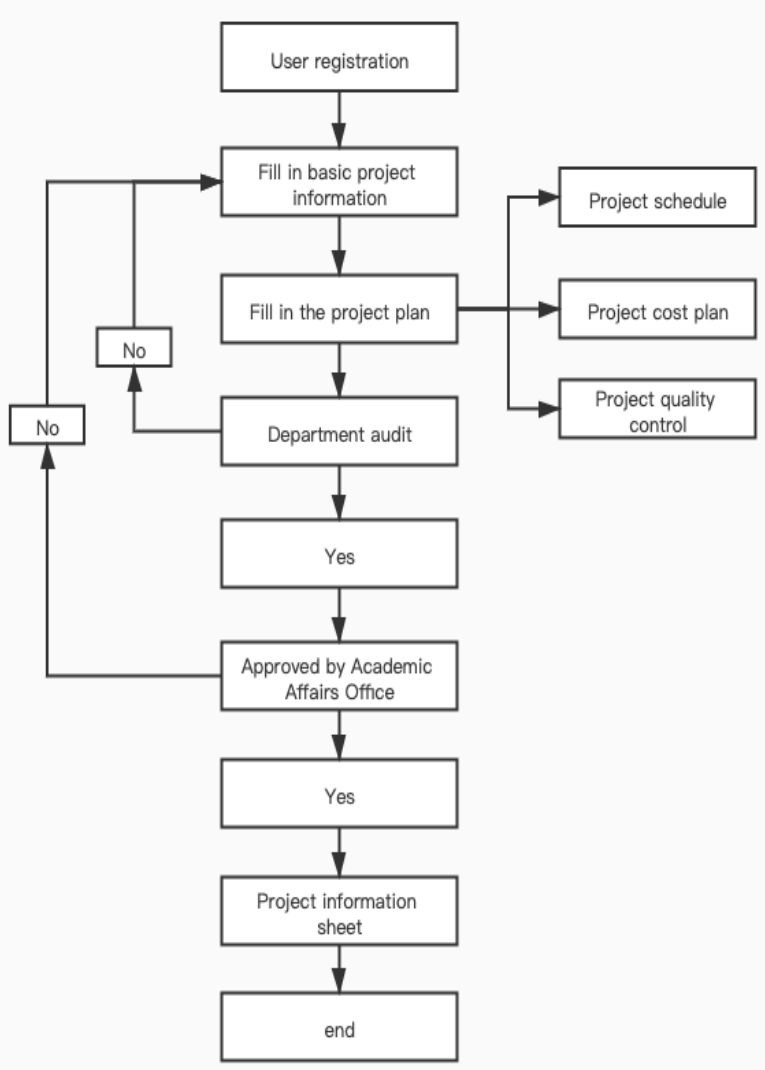

Figure 1 application flow chart of cultural and creative projects

At the beginning of each year, colleges and universities will apply for the cultural and creative projects of that year. Generally, the application process consists of individual application by students, preliminary examination by colleges and departments, review and selection by the academic affairs office. The projects are classified and submitted to the higher authorities. Finally, the cultural and creative projects are approved by the Ministry of education.

\subsection{Module 2 - Project Management}

After the project is approved successfully, the entrepreneur should manage the project and divide the project into several stages. When the project schedule is updated or the project cost is changed, the entrepreneur should change the project information in time to ensure that the manager can understand the project schedule in the first time. After the completion of each stage of the 
project, the entrepreneur should carry out quality test and fill in the quality test report Each meeting of the entrepreneurial team should keep the corresponding minutes in the project. The tutor's periodic evaluation of the project should be recorded in the platform for managers to consult at any time.

\subsection{Module 3 - Contest Registration}

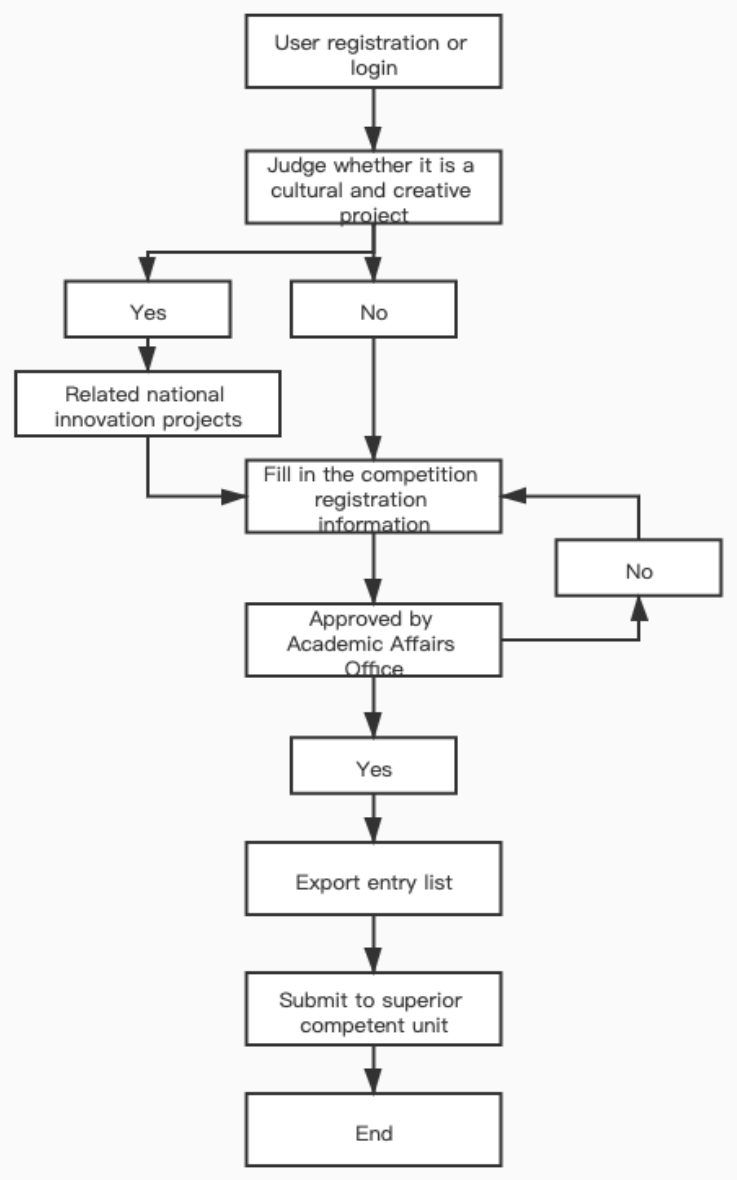

Figure 2 registration process of innovation and Entrepreneurship Competition

The innovation and entrepreneurship cloud platform of universities can provide information about competition, Internet plus competition and youth competition, as well as the process and management information of other competitions. "Internet plus contest Internet" registration process is similar to the declaration of national innovation projects, but there are some differences. Currently, some universities and colleges will participate in the "Internet plus competition". So when signing up, if the project has been registered for "Internet plus competition", the system will automatically link the relevant information of the country to create the project, so that the management can catch the core in the net review. The core elements make the selection process more scientific, the selection results more fair, and the registration process of "create youth competition" is similar to this.

\subsection{Module 4 -- curriculum system of cultural and creative innovation and Entrepreneurship}

In the process of the construction of innovation and entrepreneurship in Colleges and universities, the weakest link is the construction of curriculum system. The innovation and entrepreneurship platform provides a variety of courses for the innovation and entrepreneurship education in Colleges and universities, and provides corresponding training. The courses provided include: basic courses, which mainly enhance students' interest and enthusiasm for entrepreneurship; core courses mainly include necessary knowledge in students' entrepreneurship, such as law, finance, equity structure, intellectual property rights, management, etc.; professional integration courses help students find opportunities for innovation and entrepreneurship according to their own majors and establish appropriate innovation and entrepreneurship projects as soon as possible; Practical operation course, innovation and entrepreneurship practice course participated by teachers outside the school. The course training provided by innovation and entrepreneurship cloud platform mainly aims at the teachers inside and outside the new entrepreneurship school, and through the training, teachers can understand the key and difficult points of how to teach and the contents of the course

\subsection{Module 5 - cloud resources}

Most of the projects in the venture are related to Internet plus. Therefore, a large amount of data needs to be calculated and stored. Colleges and universities usually connect servers and storage devices to the innovation and entrepreneurship cloud platform. Entrepreneurs directly apply for the use of resources on the innovation and entrepreneurship cloud platform. After the application is passed, they obtain the qualification for the use of resources, and measure and charge according to the consumption.

\subsection{Module 6 - docking with higher authoritiesModule 5 - cloud resources}

When universities apply for the national innovation plan project, after the internal audit is passed, the platform will produce the corresponding format of project form. The project form can be submitted to the innovation and entrepreneurship cloud platform of the superior competent unit by one click. After receiving the project forms of each university, the competent unit can summarize and export excel form to the Ministry of education. The whole process is time-saving and labor-saving and not easy to make mistakes. 


\section{Significance of theoretical research on the construction of university cultural and creative innovation and entrepreneurship platform under the background of big data}

In the reform of innovation and entrepreneurship education, one of the difficulties encountered by colleges and universities is the construction of innovation and entrepreneurship tutor library. Teachers in Colleges and universities have rich theoretical knowledge and lack of practical experience in innovation and entrepreneurship, and colleges and universities lack relevant opportunities and ways of innovation and entrepreneurship teacher training. In the process of mining entrepreneurship tutors, colleges and universities also lack corresponding incentive policies and measures In the innovation and entrepreneurship education of college students, the lack of teachers leads to the lack of comprehensive, personalized and high-quality entrepreneurship guidance. According to statistics, there are many projects in universities and colleges, and many projects need to calculate and store resources in the process of entrepreneurship, especially the Internet plus contest project. All kinds of resources need to be shared and linked, and universities themselves are hard to provide to entrepreneurs in time. Some entrepreneurs choose aliyun, Tencent cloud or public cloud platform in the implementation of the project. On the other hand, it is inconvenient to find and use the relevant data of innovation and entrepreneurship on such platforms, so we need to build a cloud platform based on University Innovation and entrepreneurship to solve this problem.

Cloud gathering is an advantage and a force. The key to the construction of innovation and entrepreneurship cloud platform is to store human, material, intelligence and other related resources as the basic elements of innovation and entrepreneurship in the cloud entrepreneurship platform by using the cloud generator mechanism. Entrepreneurs can match these elements freely according to their needs. The sharing of information cloud enables entrepreneurs to understand them at the fastest speed Market demand, thus realizing the purpose of entrepreneurship.

At present, cultural and creative innovation and entrepreneurship in Colleges and universities are basically carried out through the construction of innovation and entrepreneurship Park, green innovation space, maker center and other modes. These construction modes are bound to face a lot of hardware investment and a series of resource constraints such as space resources, human resources and management resources. In the long run, it will also cause the limitations of innovation and entrepreneurship in physical space development, so we need to jump out of the concept of space We should use the concept of innovation management to explore a way of combining virtual and real, build a cloud platform of innovation and entrepreneurship in cyberspace on the basis of physical space, innovate management standards, processes and modes, and create a new mode of innovation and entrepreneurship platform for college students. The advantage of innovation and entrepreneurship cloud platform is that the cloud is everywhere, and the access points of users using the cloud platform are everywhere. Colleges and universities can set up special cloud entrepreneurship platform links and customer ports on Internet websites, campus networks and other media, so that college students can log in to the entrepreneurship platform by express, and obtain various service resources.

\section{Conclusion}

Cloud co ownership is a major advantage and concept of innovation and entrepreneurship cloud platform. Cloud combination and cloud sharing are the characteristics of cloud platform. The larger and faster the development of cloud platform, the more benefits the users of cloud platform will enjoy. The construction of cloud platform should integrate resources, share resources, seek the effect of clustering and form a community of interests under the new concept of openness, publicity and networking.

\section{ACKNOWLEDGMENT}

The role and promotion of big data on the entrepreneurship platform will bring tangible benefits to the development of social employment.

*Project No.: SZ1701 project name: Construction and practice of innovation and entrepreneurship Incubation Platform for cultural and Creative College Students

\section{References}

1. Gu Xuqiu. Discussion on the dual innovation education of accounting major in Higher Vocational Colleges Based on big data [J]. JOURNAL OF LIAONING NORMAL UNIVERSITY (SOCIAL SCIENCE EDITION), 2021 (01): 85-86

2. Jiang Huan. The organic integration of Ideological and political education and college students' innovation and entrepreneurship education in the digital economy era -Comment on "enabling digital economy: Enlightenment of big data innovation and entrepreneurship" [J]. Chinese scientific and technological paper.2021,16 (02): 251

3. notice of the provincial big data Bureau on printing and distributing the Interim Measures for the determination and management of innovation and entrepreneurship base of Guizhou big data Innovation Center [J]. Bulletin of Guizhou people's government,.2020 (12): 61-65

4. Peng Jing Song. Based on the "Internet plus" intelligent consumption, the "three innovation" education practice platform is built for [J]. modern occupation education, 2020 (48): 10-12.

5. Zhaican. Exploration and practice of advertising innovation and entrepreneurship teaching in the context of big data [j]. Introduction to news research, 2020,11 (21): 31-33 